\title{
THE TECHNOLOGICAL ADVANCEMENT OF NEW PRODUCTS, PRODUCT NEWNESS AND MARKET INFORMATION
}

\section{Dariusz Dabrowski}

\section{Introduction}

Nowadays, technological progress creates a good opportunity for companies to develop and launch products that incorporate advanced technologies. This process is particularly present in the case of high-tech companies as they are technology oriented (Im, Vorhies, Kim, \& Heiman, 2016). Firms utilize advanced technology to improve the functionality of their products and in this way they try to satisfy the customers' needs to a large extent (Kocak, Carsrud, \& Oflazoglu, 2017) and, as a consequence, to enhance the new products and the firm's performance (Chen, Tang, Jin, Xie, \& Li, 2014; Zhou, Yim, \& Tse, 2005). This seems to be a straightforward way for companies to create new products.

However, several uncertainties emerge when developing technologically advanced products. Nearly thirty years ago Bonnet (1986) pointed out that the uncertainty associated with developing and marketing new technologically advanced products is twofold. On the one hand, there is economic uncertainty due to incomplete market information about the future market outcome and on the other, there is a technical uncertainty coming from the growing complexity of the market application. Similar risks are discussed by Dhebar (2016). Therefore, this work is concentrated on the two crucial sources of risk when developing technologically advanced products, namely technology and the market. In our work, technology is represented by the technological advancement of a planned new product and the market - by obtaining market information for a new product development (NPD). Additionally, we include product newness, both to the company and to the market, as it is another source of risk related to technology as well as the market (McNally, Cavusgil, \& Calantone, 2010). Finally, our focal endogenous variable is the new product's commercial success.
The main purpose of this study is to propose that product newness and obtaining market information are mediators of the relationship between the technological advancement of a new product and the product's commercial success. The existing research suggests that the technological advancement of a new product is likely to affect its performance (Chen et al., 2014; Gao, Zhou, \& Yim, 2007; Gatignon \& Xuereb, 1997; Im et al., 2016), although little is known about the mediators that are components of this relationship. However, from the theoretical and practical perspective it is important to know what can strengthen or weaken this link. Consequently, we focus on disentangling the direct versus indirect effects of technological advancement of a new product on its commercial success, with product newness and obtaining market information as mediators.

Until now quite a lot of studies have explored the impact of technological orientation or technological innovativeness on new product performance (Chen et al., 2014; Gao et al., 2007; Gatignon \& Xuereb, 1997; Im et al., 2016; Kock, Gemünden, Salomo, \& Schultz, 2011; Zhou et al., 2005). But our study differs from the previous works and contributes to the theory of product innovation management in several ways. Firstly, our focal exogenous variable is the technological advancement of a new product that comes from technological orientation but refers to a specific new product, not to the company as a whole. In comparison to the technological innovativeness, it concerns not only the intensity of new but also existing advanced technologies that are incorporated within a product. Secondly, the mediative effects of obtaining market information have not been explored but they can be drawn from existing theories. Therefore, accessing them will enhance our knowledge about the mechanisms 
and drivers of a new product's success. Thirdly, product newness has been incorporated as mediator in the model proposed by Kock et al. (2011) but the mediation effects have not been hypothesized and statistically verified in their research. Therefore, our study takes a step forward in extending the present knowledge in this regard too.

The paper is organized as follows. Firstly, we begin by defining terms and providing the theoretical background for the model. Secondly, we develop specific hypotheses regarding the relationships between a new product's technological advancement, product performance, product newness, and obtaining market information. Thirdly, after discussing samples and measures, we present the results of testing the model. We end our paper by presenting the implications of the results, indications for future research and managerial practices.

\section{Definitions of Constructs and Theoretical Background 1.1 Definitions of Constructs}

The construct that is called the technological advancement of a new product is based on the technological orientation of a particular enterprise. Gatignon and Xuereb (1997) define a technology-oriented company as "a firm with the ability and will to acquire a substantial technological background and use it in the development of new products" (Gatignon \& Xuereb, 1997, p. 78) and by the technological advancement of a new product what is meant is the degree of advancement of the technologies embodied in a new product. This construct differs from the technological orientation as it refers directly to an individual new product and is a tactical issue, whereas technological orientation is a strategic concept that applies to the whole company. Also technological advancement is not the same as the technological newness of a new product because technological advancement covers existing, not only new technologies, as it is in the case of technological innovativeness (Kock et al., 2011). This term is used because an NPD project is specific with regard to technological advancement and product development in technology-based companies is performed with all available advanced technology, new or existing. This construct is relevant for industrial and managerial practice and can therefore be considered as an important potential driver of NPD success.

The next factor, product newness has different dimensions (Salavou \& Avlonitis, 2008) but two of them are crucial - i.e. newness to the firm and to the market (Danneels \& Kleinschmidt, 2001; McNally et al., 2010). Product newness from the company's perspective means its novelty to the company engaged in its development and - from the market's perspective - its newness to the customers. Both dimensions of product newness are a potential source of risk in NPD because product newness for the firm means a company's lack of familiarity with such an NPD project and product newness for the market means a customer's lack of familiarity with such a product (McNally et al., 2010). Consequently, in this work two constructs of product newness are considered - i.e. to the firm and to the market.

Obtaining market information is one of the fundamental activities performed by firms to be market oriented (Kohli \& Jaworski, 1990). This means that it is necessary for a company to acquire information about different entities as well as different factors in its environment. However, obtaining market information is a fairly general construct; therefore, we distinguish between market information acquired from different sources, namely from customers, competitors and other sources (e.g. distributors, suppliers).

To estimate new product performance, we measured the new product's commercial success that is represented by having achieved several commercial objectives.

\subsection{Theoretical Background}

This study draws mainly on a resource-based view of a firm (RBV). According to this theory, firms can be considered as bundles of resources that are heterogeneously distributed among them. This creates differences across firms and such a situation persists over a certain period of time. The theory assumes that if a firm has valuable, inimitable, rare and non-substitutable resources, then, by configuring them in a unique way, it is able to achieve a competitive advantage and positive outcomes over time (Barney, 1991). According to Wade and Hulland (2004), resources can be either assets (i.e. anything that can be used in the company's processes, e.g. machinery, information) or 
capabilities (i.e. patterns of actions applied to transform assets into products, e.g. skills, processes). According to this theory, a technologically advanced new product can be regarded as a company's specific asset and obtaining market information in NPD as a specific firm's capability, and these unique resources can yield competitive outcomes. However, at the same time the company and customers are faced with a certain level of product newness. Our research model is based on this principle and assumes that technologybased firms develop technologically advanced products to meet customer needs better than their competitors and, at that same time, they should be linked to the market to diminish the risks that come from product newness.

\section{Hypothesis Development 2.1 New Product Technological Advancement and Performance}

It is assumed that one of the key drivers of new product performance is the new product's technological advancement. According to the RBV theory, such resources like advanced technology and in-house knowledge of sophisticated technology - both reflected in technological product advancement - or the new product itself (Wade \& Hulland, 2004) are considered as very important resources that, when combined with other assets and capabilities (e.g. skilled personnel, a firmspecific new product process), can generate a sustained competitive advantage. The latter may be expressed as how well the new product performs in terms of both the individual project and the company itself (Henard \& McFadyen, 2012). The RBV theory leads to the expectation that incorporating advanced technology in NPD would improve product development outcomes. Hence, it is proposed:

Hypothesis 1: The technological advancement of a new product has a direct positive effect on the new product's commercial performance.

\subsection{The Mediation Effects of Product Newness}

A new product that is technologically advanced is at some level new for a company that conducts its development. If the technological advancement is greater, then the product newness for a company is likely to be greater because sophisticated technical knowledge is incorporated into its creation. But at the same time, there is a substantial justification for a relation between product newness to the company and the product's performance. An NPD project can be considered as an organizational task for a firm (Tatikonda \& Rosenthal, 2000) through which a firm transforms different inputs (e.g. materials, information) into output (e.g. new products). Each organizational task is described by certain characteristics and one of them is the degree of task uncertainty that represents "the difference between the amount of information required to perform the task and the amount of information possessed by the organization" (Galbraith, 1973, p. 5). For a firm, greater product newness means greater product development task uncertainty because such a development may be associated with dealing with some new technology and knowledge, a new product category or new market. In such a situation, the information gap is greater and the variability as well as the unpredictability of product development is larger. This is reflected in fewer task outcomes. Hence, it is assumed that an increase in technological advancement is likely to cause greater product newness to the company that, in turn, is reflected in lower commercial performance. Formally stated:

Hypothesis 2: Product newness to the company negatively mediates the relationship between technological advancement and the commercial performance of the new product.

Another innovative dimension of a new product is its newness to the market. New, technology-based products aim to mainly fulfil latent customers' needs, rather than to better satisfy their expressed needs. According to the technology acceptance model (TAM), one important determinant of actual product usage is the perceived ease of use that influences the actual product use (Davis, 1989). New products that include advanced technology may be perceived by customers as innovative, even to such an extent that customers have to learn how to use these products. On this basis, it is assumed that as the higher the new product's technological advancement, the greater its newness to the market. But product newness to the market is related to its performance. The market newness of a product can create some barriers for customers arising from a new user experience or their own resistance to 
change, try or learn new things (Trujillo, Barrios, Camacho, \& Rosa, 2010). Consequently, an increase in the market newness of a product can result in greater difficulty of usage and may lower the actual use as well as product commercial performance. Therefore, the indirect effect of technological advancement on new product performance, via product newness to the market, is likely to be negative. Hence, it is proposed:

Hypothesis 3: Product newness to the market mediates negatively the relationship between technological advancement and the commercial performance of the new product.

\subsection{The Mediation Effects of Obtaining Market Information}

The relationship between the technological advancement of new products and obtaining market information for their development is suggested by the organizational information processing concept (Tatikonda \& Rosenthal, 2000). According to Galbraith (1973) an increase in the technological advancement of a new product causes greater task uncertainty and the information requirements are greater in such cases. In order to reduce the task uncertainty, firms are likely to acquire and process information. Therefore, a higher technological advancement of a new product will likely lead to more information being obtained, including market information. Furthermore, obtaining market information is likely to affect new product performance. This can be drawn from the RBV theory. Acquiring market information in NPD is a certain firm's capability that provides a meaningful asset i.e. market information. This capability can be regarded as a firm's specific resource in NPD that leads to new product success (Henard \& McFadyen, 2012).

However, it is worth distinguishing between alternative sources of market information because of the diverse effect on performance (Dyer \& Singh, 2012; Zhang \& Yang, 2016). As we do not intend to complicate our model, we consider three types of source of market information - i.e. customers, competitors and other entities. The two first kinds of sources are treated separately because of their importance (Stejskal, Meričková, \& Prokop, 2016), while the third group includes others entities such as distributors, suppliers, industry institutions.
As an increase in technological advancement results in greater market information acquisition and this is further reflected in the higher performance of the new product, we formally propose:

Hypothesis 4: Obtaining market information from customers (H4a), competitors (H4b) and other entities (H4c) positively mediates the relationship between the technological advancement and the commercial performance of a new product.

Fig. 1 presents our conceptual model. The three mediators that measured obtaining market information from three distinct sources share at least one omitted cause - for example, the company's market familiarity - hence their disturbances were correlated as recommended by (Kline, 2012). This is also indicated by Muthen, Muthen and Asparouhov (2016) and Jose (2013).

\section{Methodology \\ 3.1 Sample and Data Collection}

A cross-sectional mail survey among hightech and medium high-tech companies was conducted to test the hypotheses in the study. These firms were chosen for two main reasons. Firstly, companies in this category are quite heavily involved in NPD. Secondly, in these firms, the degree of technology included in the products is substantially greater in comparison to lower technology firms. Hence, technological product advancement is an important issue, both for producers and customers in such industries. Additionally, such firms are faced with quicker technological and market changes than firms from other industries, therefore they are forced to monitor their markets and obtain market information.

The sampling frame consisted of firms that employed more than 49 employees within Polish high-tech and medium high-tech companies. Industries in this group were identified by using an OECD classification (OECD, 2013). According to it, high-tech firms included firms from such industries as computers and electronics, pharmaceutical, aerospace, while the medium high-tech firms were from chemical, electrical industrial machinery, automotive, medical appliances and other industries. A list of these firms was obtained from the HBI database and it was used to randomly select 792 companies that were asked to take part in the study. 


\section{Fig. 1: Conceptual research model}

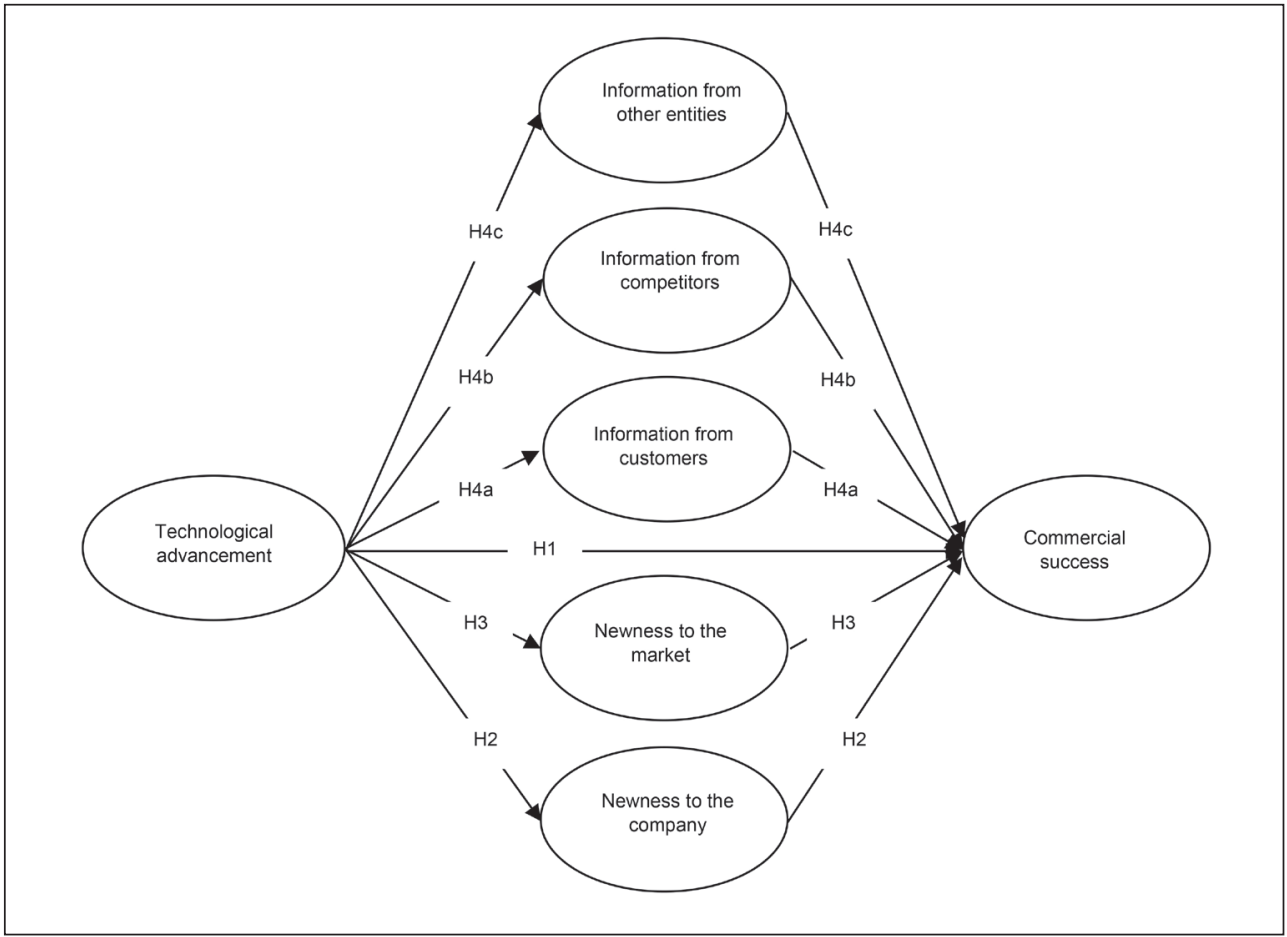

Source: own

The data collection process was performed by utilizing a fairly popular approach in NPD studies, which relies on surveying successful and unsuccessful new products (e.g. Dabrowski, 2008; Danneels \& Kleinschmidt, 2001; Tatikonda \& Rosenthal, 2000). This attitude allows the variance in the focal endogenous construct - i.e. new product performance - to be increased (Tatikonda \& Rosenthal, 2000). Each company received two versions of the same questionnaire, one related to a successful product, and the second to an unsuccessful one. The questionnaires were mailed to whoever had the highest position in the company (e.g. managing director). The recipient was asked to choose two new products that were launched at least half a year before receiving the post and to direct the relevant questionnaires to people engaged in these projects. Two follow up letters were sent - each two weeks after the former mail - in order to raise the response rate.
Before mailing the questionnaire to the firms, it was tested in a pilot study among 15 new product professionals.

Altogether, 165 companies took part in our survey, which yielded a return rate of 20.8 percent. In total, 287 valid questionnaires were received, 154 of them relating to successful and 133 to unsuccessful NPD projects. Nonresponse bias was examined by comparing groups of early and late respondents (Armstrong \& Overton, 1977). The results showed no significance differences $(p<0.05)$ in the mean for all of the constructs, suggesting that there was no non-response bias.

The final sample includes manufacturing companies of machinery and equipment (38.6\%), electrical equipment $(22.3 \%)$, chemicals and chemical products (12.0\%), computer, electronic and optical products $(7.8 \%)$, motor vehicles $(6.6 \%)$, other transport equipment $(4.2 \%)$, pharmaceutical products 
$(4.2 \%)$, medical products $(3.6 \%)$, and weapon and ammunition (0.6\%). Of these companies, 70.8 percent have from 50 to 250 employees, while 19.9 percent have between 250 to 999 employees and 9.9 percent more than 999 employees.

\subsection{Measures}

The unit of analysis in this study is the NPD project because the technological advancement of a new product, obtaining market information and product newness, both to a company and to a market, are project specific. Therefore, in the questionnaire, the respondents were asked to relate their answers to a specific NPD project. A questionnaire was designed to measure the constructs included in the conceptual model. A reflective scale of multiple items was used to measure each construct. Items were measured by applying the five-point Likert scale. Wherever possible and appropriate, existing and validated measures were used or adopted to gauge the constructs.

The measure of the technological advancement of a new product, which included four items, was based on Gatignon and Xuereb (1997) and Hultink, Talke, Griffin and Veldhuizen (2011). Ascale that contained five items was used to measure product newness to the company according to Avlonitis, Papastathopoulu and Gounaris (2001), Danneels and Kleinschmidt (2001) and Hultink et al. (2011). The market newness of a new product was measured by using five items (Hultink et al., 2011; Veldhuizen, Hultink, \& Griffin, 2006). We developed three constructs to measure the market information obtained from customers, competitors and other entities - i.e. a separate construct for a given source - based on Moorman (1995). For each of them four items were designed in such a way as to capture the essence of a construct. The construct of the new product's commercial success was ascertained according to the four items based on Veldhuizen et al. (2006). The constructs were examined in the pilot study and, together with their indicators, are presented in Appendix A.

\subsection{Reliability and Validity}

We started with a confirmatory factor analysis (CFA) to validate the measurement model fit (Gerbing \& Anderson, 1988). The CFA was performed using Mplus v.7.1 with the weighted least squares mean and variance adjusted estimator (WLSMV), which is suitable for categorical data based on the Likert-scale with five point ordinal items (Lei \& Wu, 2012; Muthén \& Muthén, 2012). According to Kline (2016), estimation methods for continuous variables are not the best choice when the indicators are Likert-scale items with five or a fewer number of categories. The fit of the model was tested using the chi-square test. However, it is sample size sensitive, so the following fit indices were also used (Wang \& Wang, 2012): Root Mean Square Error of Approximation (RMSEA), Tucker Lewis Index (TLI), Comparative Fit Index (CFI), Weighted Root Mean Square Residual (WRMR). These fit indices are provided as part of the standard output with Mplus and are recommended when categorical data are analyzed (DiStefano, Liu, Jiang, \& Shi, 2017). The hypothesized measurement model had an acceptable fit for the data: $X^{2}(384)=625.770, p<0.0001$, RMSEA $=0.047, \mathrm{TLI}=0.987, \mathrm{CFI}=0.988$, WRMR $=0.895$. The critical value of RMSEA equals 0.06 and our result does not exceed it; the coefficients TLI and CFI should not be lower than 0.95 (Hu \& Bentler, 1999), and this condition was met. The ratio $X^{2} / \mathrm{df}$ is 1.63 , which is less than 3 , and the WRMR does not exceed the critical value of 1.0 (DiStefano et al., 2017). The standardized loadings of all measurement items are highly significant and the items load on their constructs with a value of at least 0.66 , also the average variance extracted (AVE) for each of the constructs (Appendix A) exceeds 0.50 (Hair, Black, Babin, \& Anderson, 2014). Taken together, these results indicate an adequate convergent validity.

With regard to the discriminant validity, we computed the square-root of the AVE for our constructs. As shown in Tab. 1, for each construct, the square-root of the AVE is greater than the highest correlation among constructs involving the focal construct (Fornell \& Larcker, 1981). Hence, we conclude that our constructs demonstrate an adequate discriminant validity.

To assess the construct reliabilities, we computed the composite reliability (CR) measure. As shown in Appendix A, all values of the measure are well above the recommended level of 0.7 , demonstrating the internal reliability of our constructs (Bagozzi \& Yi, 2012).

Overall, based on the preceding analyses, the results suggest that the measurement model has acceptable properties. 
Tab. 1: Constructs correlations and discriminant validity

\begin{tabular}{c|c|c|c|c|c|c|c|c|c} 
& Mean & S.D. & \multicolumn{1}{|c|}{$\mathbf{1}$} & $\mathbf{2}$ & $\mathbf{3}$ & $\mathbf{4}$ & $\mathbf{5}$ & $\mathbf{6}$ & $\mathbf{7}$ \\
\hline $\begin{array}{c}\text { 1. Technological } \\
\text { advancement }\end{array}$ & 3.6 & 1.1 & 0.921 & & & & & & \\
\hline $\begin{array}{c}\text { 2. Newness } \\
\text { to the company }\end{array}$ & 2.7 & 1.1 & 0.216 & 0.760 & & & & & \\
\hline $\begin{array}{c}\text { 3. Newness } \\
\text { to the market }\end{array}$ & 2.8 & 1.3 & 0.607 & 0.242 & 0.883 & & & & \\
\hline $\begin{array}{c}\text { 4. Information } \\
\text { from customers }\end{array}$ & 3.6 & 1.0 & 0.278 & $0.012 \mathrm{~ns}$ & $0.175^{*}$ & 0.801 & & & \\
\hline $\begin{array}{c}\text { 5. Information } \\
\text { from competitors }\end{array}$ & 3.6 & 1.0 & $0.194^{*}$ & $0.018 \mathrm{~ns}$ & $0.070 \mathrm{~ns}$ & 0.373 & 0.745 & & \\
\hline $\begin{array}{c}\text { 6. Information } \\
\text { from other entities }\end{array}$ & 2.7 & 1.1 & $0.118 \mathrm{~ns}$ & 0.260 & $0.176^{*}$ & 0.212 & 0.369 & 0.885 & \\
\hline $\begin{array}{c}\text { 7. Commercial } \\
\text { success }\end{array}$ & 2.8 & 1.4 & 0.362 & $-0.030 \mathrm{~ns}$ & 0.259 & 0.456 & 0.295 & 0.225 & 0.942 \\
\hline
\end{tabular}

Source: own

Note: Off-diagonal: construct correlations; along-diagonal: square-root of AVE; ns - non significant; * $p<0.01$; in other cells $p<0.001$

Common method variance (CMV) may influence the correlations of our variables because the data were collected using a single instrument and at the same time (Malhotra, Schaller, \& Patil, 2017). CMV has been accounted for through procedural remedies and statistical techniques (Podsakoff, MacKenzie, Lee, \& Podsakoff, 2003). The procedural remedies have been addressed by ensuring respondents anonymity, reduced item ambiguity, arrangement of constructs in different sections and improved wording of items. As for statistical techniques, a CFA was used to test Harmon's single factor model. The model fits the data very poorly: $X^{2}(405)=6,026.537, p<0.0001$, WRMR $=4.685$, RMSEA $=0.220$, TLI $=0.706$, $\mathrm{CFI}=0.726$, providing that one factor solution is not acceptable and that CMV is not likely to be a problem.

\subsection{Mediation Analyses}

Mediation can be defined as a "mechanism through which the focal independent variable is able to influence the dependent variable of interest" (Baron \& Kenny, 1986, p. 1173). The variable $m$ is a mediator of the relationship between an independent variable $x$ and a dependent variable $y$ if $m$ helps to explain how and why $x$ is related to $y$ (Kraemer, Kiernan,
Essex, \& Kupfer, 2008). The proposed model in Fig. 1 is a parallel multiple mediator model that includes five mediators. According to Jose (2013), the best way to verify such a model is to use structural equation modelling (SEM). We applied SEM by using the Mplus program that allows to estimate simultaneously the significance of the direct effect, the individual indirect effects and the total effect (Muthén et al., 2016). Nowadays, this approach is recommended to verify indirect effects (Hayes \& Rockwood, 2017).

\section{Findings}

The structural model presented in Fig. 1 was estimated after validation of the measurement model (Anderson \& Gerbing, 1988). Structural equation modelling (SEM) was performed using Mplus v.7.1 applying the WLSMV method of estimation. The overall goodness-of-fit measures show that the structural model fits the data well: $X^{2}(391)=665.958, p<0.0001$, RMSEA $=0.049, \mathrm{TLI}=0.985, \mathrm{CFI}=0.987$, WRMR $=1.05$. The values of all of the fit measures are within acceptable ranges, apart from the WRMR index that slightly exceeds the critical value of 1.0. However, the WRMR has no upper limit and according to the recent study (DiStefano et al., 2017) its cut-off value might 
be slightly increased as values that are higher than 1.5 denote a problem of model fit. Also, the ratio of $X^{2}$ to the number of degree of freedoms (df) does not exceed the critical value of 3 and equals 1.70 (Hair et al., 2014).

The model in Fig. 1 is a partly mediated one, so it was compared to two other competing models (Kelloway, 2015). The first, a fully mediated model includes only the indirect relations between the technological advancement and commercial success, and the direct relation between technological advancement and commercial success is restricted to zero. The second, a non-mediated model, encompasses only the direct relations between the commercial success and other constructs, not including any mediation links.

The fully mediated model fits the data to an acceptable degree: $x^{2}(392)=684.157, p<0.0001$, RMSEA $=0.051, \mathrm{TLI}=0.984, \mathrm{CFI}=0.986$, WRMR $=1.09, X^{2} / d f=1.75$; however, all of the goodness-of-fit statistics show a slightly worse fit in comparison to the partly mediated model. The difference chi-square $D$ test for robust estimators was applied to compare the fully mediated model to the partly mediated one (Kline, 2016). The results indicated that the full mediation solution resulted in a significant decrease in model fit $\left(X_{\text {diff }}^{2}(1)=7.199\right.$, df $=392-391=1$, ss $)$; therefore, the partly mediated model provides a better solution.
Next, the non-mediated model was estimated and compared to the partly mediated one. The non-mediated model fits the data quite poorly: $X^{2}(399)=1,864.423, p<0.0001$, RMSEA $=0.113, \mathrm{TLI}=0.922, \mathrm{CFI}=0.929$, WRMR $=2.76, X^{2} / d f=4.67$. The outcomes of the difference $D$ test for robust estimators showed that the non-mediated model resulted in a significant decrease in model fit $\left(X_{\text {diff }}^{2}(8)=251.846, d f=399-391=8, s s\right)$; and it can be again concluded that the partly mediated model ensures a better solution than the non-mediated one. Therefore, the partly mediated model was chosen for further analysis and verification of the research hypotheses. Tab. 2 presents the parameter estimates and significance levels for the model in Fig. 1.

The results of verifying the hypotheses $\mathrm{H} 1-\mathrm{H} 4$ are presented in Tab. 3. In hypothesis $\mathrm{H} 1$ we proposed that technological advancement has a positive direct effect on the commercial success of new products. We found evidence that this is a case. According to Tab. 3, an increase in the technological advancement of a new product leads directly to a greater the new product's commercial success $(\beta=0.250$, $p<0.01)$. Thus, hypothesis $\mathrm{H} 1$ is supported.

Hypotheses $\mathrm{H} 2-\mathrm{H} 3$ posit that product newness, both to the company $(\mathrm{H} 2)$ and to the market $(\mathrm{H} 3)$, negatively mediates the relationship between the technological

\section{Tab. 2: Parameter estimates and significance levels}

\begin{tabular}{l|c|c|c}
\multicolumn{1}{c|}{ Effect } & $\begin{array}{c}\text { Estimate } \\
\text { (standard.) }\end{array}$ & $\begin{array}{c}\text { Standard } \\
\text { error }\end{array}$ & $p$-Value \\
\hline Technological advancement $\rightarrow$ Newness to the company & 0.285 & 0.061 & 0.000 \\
\hline Newness to the company $\rightarrow$ Commercial success & -0.146 & 0.059 & 0.013 \\
\hline Technological advancement $\rightarrow$ Newness to the market & 0.623 & 0.037 & 0.000 \\
\hline Newness to the market $\rightarrow$ Commercial success & 0.053 & 0.083 & 0.522 \\
\hline Technological advancement $\rightarrow$ Information from customers & 0.270 & 0.061 & 0.000 \\
\hline Information from customers $\rightarrow$ Commercial success & 0.338 & 0.057 & 0.000 \\
\hline Technological advancement $\rightarrow$ Information from competitors & 0.165 & 0.069 & 0.017 \\
\hline Information from competitors $\rightarrow$ Commercial success & 0.105 & 0.065 & 0.104 \\
\hline Technological advancement $\rightarrow$ Information from other entities & 0.205 & 0.064 & 0.001 \\
\hline Information from other entities $\rightarrow$ Commercial success & 0.065 & 0.065 & 0.311 \\
\hline Technological advancement $\rightarrow$ Commercial success & 0.250 & 0.092 & 0.006 \\
\hline
\end{tabular}




\section{Tab. 3: Mediation effects and results of testing hypotheses}

\begin{tabular}{l|c|c|c}
\multicolumn{1}{c|}{$\begin{array}{c}\text { Effects of technological advancement on commercial } \\
\text { success }\end{array}$} & $\begin{array}{c}\text { Estimate } \\
\text { (standardized) }\end{array}$ & $\begin{array}{c}\text { Standard } \\
\text { error }\end{array}$ & $\boldsymbol{p}$-Value \\
\hline Total effect & 0.363 & 0.056 & 0.000 \\
\hline Total indirect effect & 0.113 & 0.070 & 0.103 \\
\hline Specific indirect effects & & & \\
\hline $\begin{array}{l}\text { H2: Technological advancement } \rightarrow \text { Newness to the company } \\
\rightarrow \text { Commercial success }\end{array}$ & -0.042 & 0.019 & 0.026 \\
\hline $\begin{array}{l}\text { H3: Technological advancement } \rightarrow \text { Newness to the market } \\
\rightarrow \text { Commercial success }\end{array}$ & 0.033 & 0.051 & 0.522 \\
\hline $\begin{array}{l}\text { H4a: Technological advancement } \rightarrow \text { Information from } \\
\text { customers } \rightarrow \text { Commercial success }\end{array}$ & 0.091 & 0.027 & 0.001 \\
\hline $\begin{array}{l}\text { H4b: Technological advancement } \rightarrow \text { Information from } \\
\text { competitors } \rightarrow \text { Commercial success }\end{array}$ & 0.017 & 0.013 & 0.179 \\
\hline $\begin{array}{l}\text { H4c: Technological advancement } \rightarrow \text { Information from other } \\
\text { entities } \rightarrow \text { Commercial success }\end{array}$ & 0.013 & 0.014 & 0.322 \\
\hline $\begin{array}{l}\text { Direct effect } \\
\text { H1: Technological advancement } \rightarrow \text { Commercial success }\end{array}$ & 0.250 & 0.092 & 0.006 \\
\hline
\end{tabular}

Source: own

advancement and new product's commercial performance. We only found that product newness to the company mediates negatively this relationship $(\beta=-0.042, p<0.05)$, therefore, hypothesis $\mathrm{H} 2$ is supported. This is because, as expected and presented in Tab. 2, technological advancement has a positive effect on product newness to the company $(\beta=0.285, p<0.001)$ and, in turn, the latter affects the commercial success negatively $(\beta=-0.146, p<0.05)$. Interestingly, and contrary to the expectations in hypothesis $\mathrm{H} 3$, product newness to the market does not mediate the relationship between technological advancement and commercial success. Regarding this indirect effect (as shown in Tab. 2), the technological advancement strongly and positively affects product newness to the market $(\beta=0.623$, $p<0.001)$ but there is no significant effect between product newness to the market and its commercial success $(\beta=0.053, p>0.1)$. Thus, hypothesis $\mathrm{H} 3$ is not supported.

Hypothesis $\mathrm{H} 4$ proposed that obtaining market information - from customers $(\mathrm{H} 4 \mathrm{a})$, competitors $(\mathrm{H} 4 \mathrm{~b})$ and other entities $(\mathrm{H} 4 \mathrm{c})$ positively mediates the relationship between technological advancement and a new product's commercial success. According to
Tab. 3, the results provide only support for the mediation effect of obtaining market information from customers $(\beta=0.091, p<0.01)$. As shown in Tab. 2, the paths from technological advancement to acquiring information from customers $(\beta=0.270, p<0.001)$ and from acquiring information from customers to commercial success $(\beta=0.338, p<0.001)$ were both significant and positive, and thus, hypothesis $\mathrm{H} 4 \mathrm{a}$ was supported. However, there were no mediation effects of obtaining market information, both from competitors and from other entities. As presented in Tab. 2, despite the significant and positive effect of technological advancement on acquiring market information from competitors $(\beta=0.165, p<0.05)$ and from other entities $(\beta=0.205, p<0.01)$, the paths from obtaining market information from competitors $(\beta=0.105, p>0.1)$ and from other entities $(\beta=0.065, p>0.1)$ to commercial success were no significant. Therefore, hypotheses $\mathrm{H} 4 \mathrm{~b}$ and $\mathrm{H} 4 \mathrm{c}$ were not supported.

A sum of the direct effect and all indirect effects constitutes the total effect of the relationship between technological advancement and the new product's commercial success. This total effect, as shown in Tab. 3, is significant and positive $(\beta=0.363, p<0.001)$. 


\section{Discussion}

\subsection{Mediation Effects of Product Newness}

With regard to the two dimensions of product newness considered, we found that only product newness to the company negatively mediates the relationship between the technological advancement and commercial success of new products, while the indirect effect of product newness to the market was not significant. Exploring these indirect effects further, we observed that technological advancement results in product newness both for the company and for the market, with a much stronger effect in the latter case. However, only the newness for the company is negatively related to the commercial performance, while newness for the market has no significant effect on it. Thus, only product newness for the company negatively transforms the technological advancement of a new product into its commercial performance. These findings make the following important theoretical contributions to the literature on NPD management: in the case of technology based products only product newness to the company can be considered as an obstacle to achieving high-level commercial performance, whereas newness to the market - occurring simultaneously - is not a barrier to success. This situation can be justified as follows.

Firstly, while developing technologically advanced products, their newness to the company occurs because firms use advanced, usually complex, sometimes even new or unproven technologies, and this results in an increase in the overall product complexity and can lead to undesirable project outcomes (Tatikonda \& Rosenthal, 2000). Dealing with a non-routine task requires a greater effort from companies as well as special skills and faces higher complexity and uncertainty (Galbraith, 1973); therefore, the newness of a new product to the company can be seen as a problem that impacts a new product's commercial success.

Secondly, developing technology based products is also reflected in quite high product newness for the market, although this has no impact on the new product's commercial performance. Consequently, the technological advancement of a new product is not negatively transformed into the product's commercial performance via its newness to the market. Surprisingly, some contrary arguments state that a new product incorporating quite a large amount of advanced technology can be seen by a potential user as problematic because customers can be unfamiliar with this advanced, sophisticated technology and with how the product should be used. One plausible explanation of this situation is that may be technology-based companies are conscious of this eventual side effect and, as they really care about their customers, they already learn to cope with this problem by incorporating a reasonable level of advanced technology within their new products or by developing learning materials for customers (e.g. films on YouTube). Another explanation is - according to a remark made by one of our respondents - that some companies try to "smuggle" new technological solutions incorporated in a new product, so that customers barely notice them and are convinced of the better functionality and the user-friendliness of the product.

\subsection{Mediation Effects of Acquiring Market Information}

The second set of findings concern obtaining market information mediating the relationship between technological advancement of new products and their commercial performance. We found that this relation was mediated positively only by obtaining market information from customers and not indirectly impacted by gathering market information either from competitors or from other entities. These findings revealed an important phenomenon in the area of processing market information. Our results showed that one consequence of developing more technologically advanced products is a meaningful increase in obtaining market information from all sources - i.e. from customers, competitors as well other entities - but only acquiring market information from customers resulted in a positive effect on a new product's commercial performance. Still, the two other indirect relationships were positive but not significant. Hence, the development of technologically advanced products forces technology-based firms to look for market information from different sources - once, to reduce an informational gap that appears, and then because of their probable awareness of market being sensitive to advanced technology - but only gathering information from customers has good effect on a product's commercial success. The latter is due to the substantial role of customers in the whole NPD process 
(Feng, Cai, Zhang, \& Liu, 2016; Vayvay \& CruzCunha, 2016) and their particularly importance in a situation when a new product incorporates advanced technology. Feedback from customers seems to be critical in technology based innovations as not to harm clients with too sophisticated technological solutions.

The non-significant indirect effects of obtaining market information from both competitors and other sources appeared because acquiring market information from these sources had no significant effect on commercial product performance. In reality, competitors are not interested in revealing information that would help their rivals to create successful new products. The next source of market information - in our work referred to as other entities - represents in fact different origins of information like intermediaries, suppliers or trade associations, and each of them - as a source of market information - could differently impact the commercial performance of new products.

\subsection{Direct and Total Effect of Technological Advancement}

As expected, the technological advancement has a direct and positive effect on a new product's commercial success. This is because technologically advanced new products usually offer customers additional and new benefits by providing a greater overall functionality, and in this way customers' needs and wants are satisfied much better in comparison to existing products. This direct effect and the sum of all indirect effects constitute the total effect of technological advancement on the commercial success of new products. According to our findings, the direct effect plays the major role in the total effect, while the indirect effects are minority, but still important. Both direct and indirect effects enhance the commercial success of a new product and therefore the total effect of the technological advancement of new products is positive and fairly strong. These findings extend our present knowledge about mechanisms of affecting a technology based a new product's commercial success by disentangling the direct versus indirect effects.

\subsection{Managerial Implications}

Our study has important implications for hightech and medium high-tech companies. Firstly, managers should be aware of potential barriers while incorporating advanced technology into a new product. Product newness both to the company and to the market are consequences of employing sophisticated technology in a new product but only novelty to the firm is an obstacle. An increase in product newness to the firm is connected with a less familiar, more complex and more uncertain product development project, and such an increase is likely to negatively influence a new product's commercial performance. To overcome this obstacle, we would recommend companies train NPD personnel in ways of dealing with new tasks and situations. The second potential side effect involves the quite meaningful increase in product newness for potential users, as they are faced with new solutions or ways of using a product. Here, we have not observed a significant impact of product newness on its commercial success, maybe due to special strategies or learning practices for customers applied by firms.

Secondly, our results underline the role of facilitators of technology-based NPD in the form of obtaining market information. We observed that an increase in technological advancement is associated with a greater effort in gathering market information from different sources. However, only obtaining market information from customers mediates positively and supports the relation between a product's technological advancement and its commercial success. Therefore, obtaining market information from potential users of a new product will be a "bridge" between sophisticated technology and the customer. In this way, customers' expectations and preferences, attitudes and product evaluations can be gained in order to reduce the gap between technological complexity and market requirements. Hence, we suggest that hightech and medium high-tech companies establish firm links with potential new product users to obtain information from them. Still, effort made to acquire market information from competitors and other sources is important the observed mediation effects were positive - but without a meaningful impact on the new product's success. Therefore, we recommend technology-based companies to concentrate much more on customers than on other parties when creating technologically advanced new products. This should increase the chance of success. 
Thirdly, knowing some facilitators of and obstacles to technology-based new products, still the main driver of their success is the employment of advanced technology because such products offer a broader and better functionality, and this in regard has a favorable effect on the product's usefulness for customers. But this link can be strengthened by managerial practices of obtaining market information during NPD, particularly from potential customers, and weakened by product newness to the company. Therefore, we recommend medium and hightech companies apply an advanced and sophisticated technology in their NPD and at the same time, on the one hand, control and reduce the side effect of product newness to the firm and, on the other hand, strengthen this link by concentrating on communication with potential buyers. The overall effect of developing a new product based on advanced technology is very likely to be positive concerning its commercial performance.

\subsection{Limitations and Directions for Future Research}

This study is based on a standard research concept but it has some limitations. Firstly, we rely on cross-sectional data set and it limits examination of causal relationships. However, we study effects that are based on grounded theories and in this way they are substantially supported. Secondly, the commercial performance of a new product was measured by perception-based subjective measures. Future studies could consider to apply objective performance data (e.g. sales of a new product) to validate our results. Thirdly, to explain the positive effect of the technological advancement on a new products' commercial success, we used two types of mediators i.e. product newness and obtaining market information. Yet, we can try to study this link further by including other mediators, such as product functionality, ease of use or the perceived usefulness of a new product that is technologically advanced. This issue can be addressed by further research. Fourthly, the current study provides the results of the mediation effects, originating from product newness and obtaining market information, between the technological advancement and new product's commercial success across hightech and medium high-tech firms in Poland. Therefore, generalizations on the outcomes to a specific firm, employing certain ways of obtaining market information, should be made with caution. Future research could be directed to study these relationships in industries that use disparate degrees of technology and in different countries. Fifthly, in this work, it was assumed a positive linear relationship between the technological advancement and the product's commercial success. But, overall, the shape of the relationship is probably like an inverted " $u$ " because excessive technological advancement will result in burdensome problems and changes, both for the firm and for the customer, which might negatively invert this effect. The assumption of a linear link is based on a belief that, in practice, most new products exhibit a reasonable level of technological advancement, and therefore, this approximation is sufficient. However, such a conviction can be verified by studying products with a high level of differentiation in terms of technological advancement. Also, such a potential future study can result in finding the optimal amount of technological product advancement.

\section{Conclusions}

This study provides quite strong empirical evidence that the direct effect is the main driver of the commercial success of technologically advanced new products as such product provides broader and better functionality to customers. However, this effect is influenced by indirect effects that are both negative and positive.

We observed that along with an increase in the technological advancement of a new product, product newness is greater, both for the company and for the market. However, only novelty to the firm mediates negatively the relationship between the technological advancement and the commercial success of new products, whereas novelty to the market does not. Therefore, the crucial obstacle that should be controlled and reduced with such developments is product newness to the company. Product newness to the market is not problematic and, one might suppose, such practices as obtaining market information could be one solution for this.

Our work provides evidence that obtaining market information from customers mediates positively the relationship between technological advancement and new products' commercial success. Despite the fact that an increase in 
technological advancement will cause a greater effort to be expended in obtaining market information from customers and competitors as well as other entities, our results show that only acquiring market information from customers transforms the technological advancement into the commercial success of a new product. Indirect effects of obtaining market information from competitors and other entities are positive but not significant. Therefore, when creating technologically advanced new products, more concentration on customers will translate into greater commercial success.

\section{References}

Anderson, J. C., \& Gerbing, D. W. (1988). Structural equation modeling in practice: A review and recommended two-step approach. Psychological Bulletin, 103(3), 411-423. https://doi.org/10.1037/0033-2909.103.3.411.

Armstrong, J. S., \& Overton, T. S. (1977). Estimating nonresponse bias in mail surveys. Journal of Marketing Research, 14(3), 396-402. https://doi.org/10.2307/3150783.

Avlonitis, G. J., Papastathopoulu, P. G., \& Gounaris, S. P. (2001). An empiricallybased typology of product innovativeness for new financial services: Success and failure scenarios. Journal of Product Innovation Management, 18(5), 324-342. https://doi. org/10.1111/1540-5885.1850324.

Bagozzi, R. P., \& Yi, Y. (2012). Specification, evaluation, and interpretation of structural equation models. Journal of the Academy of Marketing Science, 40(1), 8-34. https://doi. org/10.1007/s11747-011-0278-x.

Barney, J. (1991). Firm resources and sustained competitive advantage. Journal of Management, 17(1), 99-120. https://doi. org/10.1177/014920639101700108.

Baron, R. M., \& Kenny, D. A. (1986). The moderator-mediator variable distinction in social psychological research: conceptual, strategic, and statistical considerations. Journal of Personality and Social Psychology, 51(6), 1173-1182. https://doi.org/10.1037/00223514.51.6.1173.

Bonnet, D. C. L. (1986). Nature of the R\&D/Marketing co-operation in the design of technologically advanced new industrial products. R\&D Management, 16(2), 117-126. https://doi.org/10.1111/j.1467-9310.1986.tb01165.x.
Chen, Y., Tang, G., Jin, J., Xie, Q., \& Li, J. (2014). CEOs' transformational leadership and product innovation performance: The roles of corporate entrepreneurship and technology orientation. Journal of Product Innovation Management, 31(S1), 2-17. https://doi. org/10.1111/jpim.12188.

Dabrowski, D. (2008). New product practices and performance of German appliances companies. Argumenta Oeconomica, 2(21), 153-176.

Danneels, E., \& Kleinschmidt, E. J. (2001). Product innovativeness from the firm's perspective: Its dimensions and their relation with project selection and performance. Journal of Product Innovation Management, 18(6), 357-373. https://doi.org/10.1111/15405885.1860357.

Davis, F. D. (1989). Perceived usefulness, perceived ease of use, and user acceptance of information technology. Information Systems Journal, 13, 319-340. https://doi. org/10.2307/249008.

Dhebar, A. (2016). Bringing new hightechnology products to market: Six perils awaiting marketers. Business Horizons, 59(6), 713-722. https://doi.org/10.1016/j. bushor.2016.08.006.

DiStefano, C., Liu, J., Jiang, N., \& Shi, D. (2017). Examination of the weighted root mean square residual: Evidence for trustworthiness? Structural Equation Modeling, 25(3), 1-14. https://doi.org/10.1080/10705511.2017.1390394.

Dyer, J. H., \& Singh, H. (2012). The relational view: cooperate strategy and sources of interorganizational competitive advantage. The Academy of Management Review, 23(4), 660-679. https://doi.org/10.7880/abas.13.77.

Feng, T., Cai, D., Zhang, Z., \& Liu, B. (2016). Customer involvement and new product performance: The jointly moderating effects of technological and market newness. Industrial Management \& Data Systems, 116(8), 1700-1718. https://doi.org/10.1108/IMDS-11-2015-0457.

Fornell, C., \& Larcker, D. F. (1981). Evaluating structural equation models with unobservable variables and measurement error. Journal of Marketing Research, 18(1), 39-50. https://doi.org/10.2307/3151312.

Galbraith, J. (1973). Designing Complex Organizations. Boston: Addison-Wesley Longman Publishing Co.

Gao, G. Y., Zhou, K. Z., \& (Bennet) Yim, C. K. (2007). On what should firms focus in transitional 
economies? A study of the contingent value of strategic orientations in China. International Journal of Research in Marketing, 24(1), 3-15. https://doi.org/10.1016/j.jiresmar.2006.09.004.

Gatignon, H., \& Xuereb, J. (1997). Strategic orientation of the firm and new product performance. Journal of Marketing Research, 34(1), 77-90. https://doi.org/10.2307/3152066.

Gerbing, D. W., \& Anderson, J. C. (1988). An updated paradigm for scale development incorporating unidimensionality and its assessment. Journal of Marketing Research, 25(2), 186-192. https://doi. org/10.2307/3172650.

Griffin, A., \& Page, A. L. (1996). PDMA success measurement project: Recommended measures for product development success and failure. Journal of Product Innovation Management, 13(6), 478-496. https://doi. org/10.1111/1540-5885.1360478.

Hair, J. F., Black, W. C., Babin, B. J., \& Anderson, R. E. (2014). Multivariate data analysis (7th ed.). Edinburgh Gate: Pearson Education.

Hayes, A. F., \& Rockwood, N. J. (2017). Regression-based statistical mediation and moderation analysis in clinical research: Observations, recommendations, and implementation. Behaviour Research and Therapy, 98, 39-57. https://doi.org/10.1016/j. brat.2016.11.001.

Henard, D. H., \& McFadyen, M. A. (2012). Resource dedication and new product performance: A resource-based view. Journal of Product Innovation Management, 29(2), 193-204. https://doi.org/10.1111/j.1540-5885. 2011.00889.x.

Hu, L. T., \& Bentler, P. M. (1999). Cutoff criteria for fit indexes in covariance structure analysis: Conventional criteria versus new alternatives. Structural Equation Modeling, 6(1), 1-55. https://doi.org/10.1080/10705519909540118.

Hultink, E. J., Talke, K., Griffin, A., \& Veldhuizen, E. (2011). Market information processing in new product development: The importance of process interdependency and data quality. IEEE Transactions on Engineering Management, 58(2), 199-211. https://doi. org/10.1109/TEM.2009.2034254.

Im, S., Vorhies, D. W., Kim, N., \& Heiman, B. (2016). How knowledge management capabilities help leverage knowledge resources and strategic orientation for new product advantages in B-to-B high-technology firms. Journal of Business-to-Business Marketing,
23(2), 87-110. https://doi.org/10.1080/105171 2X.2016.1169067.

Jose, P. E. (2013). Doing statistical mediation and moderation. New York: The Guilford Press.

Kelloway, E. K. (2015). Using Mplus for Structural Equation Modeling. A Researcher's Guide. London: Sage Publications.

Kline, R. B. (2012). Assumptions in structural equation modeling. In R. H. Hoyle (Ed.), Handbook of structural equation modeling (pp. 111-125). New York: The Guliford Press.

Kline, R. B. (2016). Principles and practice of structural equation modeling. New York: Guliford Press.

Kocak, A., Carsrud, A., \& Oflazoglu, S. (2017). Market, entrepreneurial, and technology orientations: impact on innovation and firm performance. Management Decision, 55(2), 248-270. https://doi.org/10.1108/MD-04-20150146.

Kock, A., Gemünden, H. G., Salomo, S., \& Schultz, C. (2011). The mixed blessings of technological innovativeness for the commercial success of new products. Journal of Product Innovation Management, 28(s1), 28-43. https:// doi.org/10.1111/j.1540-5885.2011.00859.x.

Kohli, A. K., \& Jaworski, B. J. (1990). Market orientation: The construct, research propositions, and managerial implications. Journal of Marketing, 54(2), 1-18. https://doi. org/10.1177/002224299005400201.

Kraemer, H. C., Kiernan, M., Essex, M., \& Kupfer, D. J. (2008). How and why criteria defining moderators and mediators differ between the Baron \& Kenny and MacArthur approaches. Health Psychology, 27(2 Suppl), S101-S108. https://doi.org/10.1037/0278-6133. 27.2(Suppl.).S101.

Lei, P.-W., \& Wu, Q. (2012). Estimation in structural equation modeling. In R. H. Hoyle (Ed.), Handbook of structural equation modeling (pp. 164-180). New York: The Guliford Press.

Malhotra, N. K., Schaller, T. K., \& Patil, A. (2017). Common method variance in advertising research: When to be concerned and how to control for it. Journal of Advertising, 46(1), 193-212. https://doi.org/10.1080/009133 67.2016.1252287.

McNally, R. C., Cavusgil, E., \& Calantone, R. J. (2010). Product innovativeness dimensions and their relationships with product advantage, product financial performance, and project protocol. Journal of Product Innovation 
Management, 27(7), 991-1006. https://doi. org/10.1111/j.1540-5885.2010.00766.x.

Moorman, C. (1995). Organizational market information processes: cultural antecedents and new product outcomes. Journal of Marketing Research, 32(3), 318-335. https:// doi.org/10.2307/3151984.

Muthén, B. O., Muthén, L., \& Asparouhov, T. (2016). Regression and mediation analysis using Mplus. Los Angeles: CA: Muthen \& Muthen.

Muthén, L. K., \& Muthén, B. O. (2012). Mplus user's guide (7th ed.). Los Angeles: CA: Muthén \& Muthén.

OECD. (2013). OECD Science, Technology and Industry Scoreboard 2013. https://doi. org/10.1787/sti_scoreboard-2013-en.

Podsakoff, P. M., MacKenzie, S. B., Lee, J.Y., \& Podsakoff, N. P. (2003). Common method biases in behavioral research: A critical review of the literature and recommended remedies. Journal of Applied Psychology, 88(5), 879-903. https://doi.org/10.1037/0021-9010.88.5.879.

Salavou, H., \& Avlonitis, G. (2008). Product innovativeness and performance: a focus on SMEs. Management Decision, 46(7), 969-985. https://doi.org/10.1108/00251740810890168.

Stejskal, J., Mikušová Meričková, B., \& Prokop, V. (2016). The cooperation between enterprises: Significant part of the innovation process - A case study of the Czech machinery industry. E\&M Ekonomie a Management, 19(3), 110-122. https://doi.org/10.15240/tul/001/20163-008.

Tatikonda, M. V., \& Rosenthal, S. R. (2000). Technology novelty, project complexity, and product development project execution success: A deeper look at task uncertainty in product innovation. IEEE Transactions on Engineering Management, 47(1), 74-87. https:// doi.org/10.1109/17.820727.

Trujillo, C. A., Barrios, A., Camacho, S. M., \& Rosa, J. A. (2010). Low socioeconomic class and consumer complexity expectations for new product technology. Journal of Business Research, 63(6), 538-547. https://doi. org/10.1016/j.jbusres.2009.05.010.

Vayvay, Ö., \& Cruz-Cunha, M. M. (2016). Supplier involvement in new product development: a case study from the semiconductor industry. E\&M Ekonomie a Management, 19(3), 123-141. https://doi. org/10.15240/tul/001/2016-3-009.

Veldhuizen, E., Hultink, E. J., \& Griffin, A. (2006). Modeling market information processing in new product development: An empirical analysis. Journal of Engineering and Technology Management, 23(4), 353-373. https://doi. org/10.1016/j.jengtecman.2006.08.005.

Wade, M., \& Hulland, J. (2004). The resource-based view and information systems research: review, extension, and suggestions for future research. MIS Quarterly, 28(1), 107142. https://doi.org/10.2307/25148626.

Wang, J., \& Wang, X. (2012). Structural Equation Modeling. Applications Using Mplus. Chichester, West Sussex: John Wiley \& Sons.

Zhang, H., \& Yang, F. (2016). The impact of external involvement on new product market performance: An analysis of mediation and moderation. Industrial Management \& Data Systems, 116(8), 1520-1539. https://doi. org/10.1108/IMDS-11-2015-0485.

Zhou, K. Z., Yim, C. K. (Bennett), \& Tse, D. K. (2005). The effects of strategic orientations on technology- and market-based breakthrough innovations. Journal of Marketing, 69(2), 42-60. https://doi.org/10.1509/jmkg.69.2.42.60756.

Dr hab. Ing. Dariusz Dabrowski, Assoc. Prof. Gdansk University of Technology Faculty of Management and Economics Department of Marketing Poland dariusz.dabrowski@zie.pg.gda.pl 


\section{Appendix A: Constructs, reliability and validity coefficients (Part 1)}

\begin{tabular}{|c|c|c|c|c|c|}
\hline Latent variables & Indicators & $\lambda$ & $t$-values & CR & AVE \\
\hline Technological advancement & & & & 0.957 & 0.848 \\
\hline \multirow{4}{*}{$\begin{array}{l}\text { Adopted from: Gatignon } \\
\text { and Xuereb (1997), Hultink et } \\
\text { al. (2011) }\end{array}$} & $\begin{array}{l}\text { The new product is advanced in } \\
\text { terms of technology. }\end{array}$ & 0.900 & 62.3 & & \\
\hline & $\begin{array}{l}\text { The new product is based on a lot } \\
\text { of technical knowledge. }\end{array}$ & 0.911 & 73.7 & & \\
\hline & $\begin{array}{l}\text { The new product is based on } \\
\text { advanced technology. }\end{array}$ & 0.919 & 84.4 & & \\
\hline & $\begin{array}{l}\text { The new product is technically } \\
\text { complex. }\end{array}$ & 0.952 & 88.4 & & \\
\hline Newness to the company & & & & 0.871 & 0.577 \\
\hline \multirow{5}{*}{$\begin{array}{l}\text { Adopted from: Avlonitis } \\
\text { et al. (2001), Danneels } \\
\text { and Kleinschmidt (2001), } \\
\text { Hultink et al. (2011) }\end{array}$} & $\begin{array}{l}\text { This product category was new to } \\
\text { our firm. }\end{array}$ & 0.663 & 16.0 & & \\
\hline & $\begin{array}{l}\text { The customers for this product were } \\
\text { new to our company. }\end{array}$ & 0.762 & 20.8 & & \\
\hline & $\begin{array}{l}\text { Our competitors were new to our } \\
\text { company }\end{array}$ & 0.739 & 21.7 & & \\
\hline & $\begin{array}{l}\text { The marketing strategy for the } \\
\text { product was new to our company. }\end{array}$ & 0.781 & 26.2 & & \\
\hline & $\begin{array}{l}\text { The market environment for the } \\
\text { product was new to our firm. }\end{array}$ & 0.842 & 31.0 & & \\
\hline Newness to the market & & & & 0.946 & 0.779 \\
\hline \multirow{5}{*}{$\begin{array}{l}\text { Adopted from: Hultink } \\
\text { et al. (2011), Veldhuizen } \\
\text { et al. (2006) }\end{array}$} & $\begin{array}{l}\text { When the new product was launched } \\
\text { it was innovative for the market. }\end{array}$ & 0.873 & 50.2 & & \\
\hline & $\begin{array}{l}\text { When the new product was launched } \\
\text { there were no comparable products } \\
\text { on the market. }\end{array}$ & 0.834 & 39.3 & & \\
\hline & $\begin{array}{l}\text { When the new product was launched } \\
\text { it was new for the product category. }\end{array}$ & 0.869 & 48.8 & & \\
\hline & $\begin{array}{l}\text { When the new product was launched } \\
\text { it was the first of its kind. }\end{array}$ & 0.901 & 54.3 & & \\
\hline & $\begin{array}{l}\text { When the new product was launched } \\
\text { it had features that did not exist yet. }\end{array}$ & 0.933 & 69.8 & & \\
\hline Information from customers & & & & 0.877 & 0.642 \\
\hline \multirow[t]{4}{*}{$\begin{array}{l}\text { New, based on Moorman } \\
\text { (1995) }\end{array}$} & $\begin{array}{l}\text { We gathered market information from } \\
\text { potential buyers. }\end{array}$ & 0.786 & 24.8 & & \\
\hline & $\begin{array}{l}\text { Target customers were a source } \\
\text { of information about their needs. }\end{array}$ & 0.757 & 22.0 & & \\
\hline & $\begin{array}{l}\text { We gathered market information } \\
\text { from customers on different stages } \\
\text { of NPD. }\end{array}$ & 0.778 & 26.7 & & \\
\hline & $\begin{array}{l}\text { We obtained market information } \\
\text { several times from future customers. }\end{array}$ & 0.878 & 29.4 & & \\
\hline
\end{tabular}




\section{Appendix A: Constructs, reliability and validity coefficients (Part 2)}

\begin{tabular}{|c|c|c|c|c|c|}
\hline Latent variables & Indicators & $\lambda$ & $t$-values & CR & AVE \\
\hline $\begin{array}{l}\text { Information from } \\
\text { competitors }\end{array}$ & & & & 0.833 & 0.555 \\
\hline \multirow[t]{4}{*}{$\begin{array}{l}\text { New, based on Moorman } \\
\text { (1995) }\end{array}$} & $\begin{array}{l}\text { We gathered market information from } \\
\text { potential competitors } \\
\text { (e.g. at fairs, meetings or through } \\
\text { personal contacts). }\end{array}$ & 0.688 & 14.1 & & \\
\hline & $\begin{array}{l}\text { We analysed competitive products to } \\
\text { the new product. }\end{array}$ & 0.796 & 21.0 & & \\
\hline & $\begin{array}{l}\text { Web sites of prospective competitors, } \\
\text { their materials and promotional } \\
\text { activities were a source of } \\
\text { information about them. }\end{array}$ & 0.751 & 21.3 & & \\
\hline & $\begin{array}{l}\text { We observed the behaviour } \\
\text { of prospective competitors. }\end{array}$ & 0.742 & 20.6 & & \\
\hline $\begin{array}{l}\text { Information from other } \\
\text { entities }\end{array}$ & & & & 0.935 & 0.783 \\
\hline \multirow[t]{4}{*}{$\begin{array}{l}\text { New, based on Moorman } \\
\text { (1995) }\end{array}$} & $\begin{array}{l}\text { Other market entities } \\
\text { (e.g. intermediaries, suppliers, trade } \\
\text { associations, experts) were a source } \\
\text { of information about the market for } \\
\text { this product. }\end{array}$ & 0.857 & 45.2 & & \\
\hline & $\begin{array}{l}\text { Through these other entities we } \\
\text { have gained information about future } \\
\text { buyers and competitors. }\end{array}$ & 0.882 & 49.3 & & \\
\hline & $\begin{array}{l}\text { We contacted the other entities } \\
\text { several times to gain information } \\
\text { about the market. }\end{array}$ & 0.918 & 61.2 & & \\
\hline & $\begin{array}{l}\text { We obtained a lot of market } \\
\text { information from these entities. }\end{array}$ & 0.881 & 49.7 & & \\
\hline Commercial success & & & & 0.969 & 0.887 \\
\hline \multirow{4}{*}{$\begin{array}{l}\text { Adopted from: Griffin and } \\
\text { Page (1996), Veldhuizen et } \\
\text { al. (2006) }\end{array}$} & $\begin{array}{l}\text { The new product achieved unit sales } \\
\text { goals. }\end{array}$ & 0.969 & 156.1 & & \\
\hline & $\begin{array}{l}\text { The new product achieved revenue } \\
\text { growth sales. }\end{array}$ & 0.944 & 102.6 & & \\
\hline & $\begin{array}{l}\text { The new product achieved market } \\
\text { share goals. }\end{array}$ & 0.932 & 85.8 & & \\
\hline & $\begin{array}{l}\text { The new product achieved sufficient } \\
\text { sales as a percentage of total } \\
\text { company sales. }\end{array}$ & 0.922 & 78.4 & & \\
\hline
\end{tabular}

Note: $\lambda$ - Standardised loadings; CR - Construct reliability; AVE - Average variance extracted. 


\section{Abstract}

\section{THE TECHNOLOGICAL ADVANCEMENT OF NEW PRODUCTS, PRODUCT NEWNESS AND MARKET INFORMATION}

\section{Dariusz Dabrowski}

The purpose of this study is to propose product newness and obtaining market information as mediators of the relationship between the technological advancement of a new product and its commercial success. So far, little is known about the mediators of this relationship but knowledge about the factors that strengthen or weaken it is valid, both for the theory and practice of new product management. On the one hand, product newness - those elements that constitute its novelty to the company and to the market - is hypothesized as a factor that weakens the relationship while, on the other hand, obtaining market information - information gathered from customers, competitors and other sources - is expected to strengthen it.

This research is based on data regarding 287 new products developed by Polish high-tech and medium high-tech companies. Confirmatory factor analysis and structural equation modelling were applied to test the parallel multiple mediator model.

The results of this research show that the positive effect of the technological advancement of a new product on its commercial performance is mediated, on the one hand, negatively by product newness to the company and, on the other hand, positively by gathering market information from customers. Neither product newness to the market nor obtaining market information from competitors or from other entities cause any indirect effects.

While developing technologically advanced products, it is recommend to train new product development staff in ways of dealing with new tasks and situations that arise during such developments, and also to focus more on gathering market information from customers than from competitors or other entities because this will positively influence the new products' success.

Key Words: New products management, technological advancement, product newness, market information, high-tech.

JEL Classification: 031, O32, M31.

DOI: 10.15240/tul/001/2019-3-011 